\title{
Urban Pauli
}

Uniwersytet Ekonomiczny w Krakowie

e-mail: urban.pauli@uek.krakow.pl

\section{MIGRACJA JAKO SZANSA NA WZBOGACANIE KAPITAŁU LUDZKIEGO - DOŚWIADCZENIE POLSKICH PRZEDSIĘBIORCÓW*}

\section{MIGRATION AS AN OPPORTUNITY FOR HUMAN CAPITAL ENHANCEMENT - POLISH ENTREPRENEURS EXPERIENCE}

DOI: $10.15611 / \mathrm{pn} .2018 .512 .16$

JEL Classification: J24, L26, M54

Streszczenie: Celem artykułu jest ocena wpływu migracji zarobkowej na poszerzanie wiedzy i rozwój umiejętności osób, które po powrocie założyły własną działalność gospodarczą. Jeśli przyjąć perspektywę rynku pracy, migracja może być procesem, w którym następuje wzbogacanie komponentów kapitału ludzkiego, co pozytywnie wpływa na wymianę wiedzy i umiejętności między krajami (brain circulation) oraz na rozwój osobisty migranta. W artykule zaprezentowano wyniki badań przeprowadzonych wśród 54 przedsiębiorców, którzy wyemigrowali do Europy Zachodniej, a po powrocie założyli własne firmy. Uzyskane wyniki wskazują, że w trakcie pobytu za granicą większość z nich pozyskała nową wiedzę, rozwinęła umiejętności, zidentyfikowała/rozwinęła swoje predyspozycje, a także opracowała koncepcję własnej firmy.

Słowa kluczowe: kapitał ludzki, przedsiębiorczość, migracja.

Summary: The main aim of this paper is to discuss the impact of labour migration on knowledge and skills development. In the article the results of the research conducted on a group of 54 Polish entrepreneurs are presented. They migrated to West European countries and after returning they decided to set up own businesses. The data show that migration provided them with an opportunity to increase knowledge, develop skills and identify or strengthen their abilities. Thus, it can be concluded that migration contributed to the development of human capital among the investigated entrepreneurs, which also supports the concept of brain circulation.

Keywords: human capital, migration, entrepreneurship.

* Artykuł powstał w ramach grantu na podtrzymanie potencjału badawczego nr 072/WE-KZKL/02/2017/S/7072 realizowanego przez Katedrę Zarządzania Kapitałem Ludzkim Uniwersytetu Ekonomicznego w Krakowie, finansowanego przez Ministerstwo Nauki i Szkolnictwa Wyższego. 


\section{Wstęp}

Migracja zarobkowa jest procesem o kluczowym znaczeniu dla kształtowania się rynku pracy w Europie. Sytuacja ta dotyczy w szczególności Polski, która po przystąpieniu do Unii Europejskiej zanotowała znaczny odpływ pracowników. W debacie dotyczącej skutków migracji szczególną uwagę zwracano na negatywne skutki wyjazdu osób o wysokim potencjale i kwalifikacjach i wskazywano, że Polska może doświadczyć zjawiska „drenażu mózgów” (brain drain). Ostatnie badania dotyczące migracji zarobkowej wskazują jednak, że można ją traktować jako jeden z etapów aktywności zawodowej. Część osób po spędzeniu kilku lat za granicą podejmuje decyzję o powrocie, co jest uwarunkowane m.in.: tęsknotą za rodziną, problemami z aklimatyzacją, osiągnięciem zakładanych celów zawodowych, zwiększeniem szans na znalezienie pracy w Polsce, poprawą sytuacji gospodarczej w kraju, poprawą sytuacji materialnej czy możliwością założenia własnej firmy. W sytuacji tej w większym stopniu następuje zjawisko wymiany/cyrkulacji kapitału ludzkiego (niż „drenażu mózgów”), co przynosi korzyści dla kraju ojczystego, przyjmującego i samego pracownika.

Głównym problemem badawczym, który został podjęty w tym artykule, jest zagadnienie wzbogacania kapitału ludzkiego polskich przedsiębiorców w trakcie ich pobytu za granicą. W badaniach przyjęto, że wiedza, umiejętności i postawy potrzebne w prowadzeniu działalności gospodarczej mogą być rozwijane i nabywane poprzez zróżnicowane doświadczenia zawodowe i pozazawodowe, jakich doświadcza jednostka, będąc na migracji. Głównymi pytaniami, które zostały sformułowane na etapie konceptualizacji badań, były: (1) Czy osoby, które powrócity do Polski z migracji zarobkowej, pozyskaty za granica nowa wiedzę?; (2) Czy rozwinęly umiejętności?; (3) Czy nabyty/zidentyfikowaty/rozwinęty swoje postawy, predyspozycje?; (4) W jaki sposób rozwijaly/nabywaly te komponenty KL?; (5) Czy sq one wykorzystywane w prowadzeniu własnej działalności?.

\section{Teoretyczne podstawy badań}

\subsection{Sposoby wzbogacania kapitału ludzkiego}

Kapitał ludzki definiowany jest jako ogół wiedzy, umiejętności, zdolności, postaw i wartości ucieleśnionych w ludziach, które mają określoną wartość i stanowią źródło dochodów dla właściciela kapitału ludzkiego [Pocztowski 2007, s. 41]. Część z wymienionych komponentów jest wrodzona i nie podlega modyfikacjom, część natomiast może stanowić przedmiot rozwoju i doskonalenia. Działania podejmowane w celu wzbogacenia kapitału ludzkiego traktowane są jako inwestycje, gdyż wymagają ponoszenia nakładów finansowych i niefinansowych oraz obarczone są ryzykiem [Lipka 2010, s. 32]. Inwestycje te mogą przybierać zróżnicowane formy, które w sposób ogólny można zaklasyfikować do jednej z czterech kategorii zapro- 
ponowanych przez G. Beckera [1962]: aktywność na stanowisku pracy, edukacja, inwestycje w inne rodzaje wiedzy i płaca zasadnicza. Mając na uwadze cel artykułu, w prowadzonych rozważaniach uwzględniono te działania ukierunkowane na wzbogacanie kapitału ludzkiego, które mogą być realizowane przez osobę, która podjęła decyzję o migracji. W ramach tych aktywności wymienić należy w szczególności:

- szkolenia realizowane przez instytucje rynkowe umożliwiające pozyskanie wiedzy i umiejętności ogólnych lub specyficznych (takich, które mogą być wykorzystane w wąskiej grupie organizacji lub stanowisk),

- konferencje, seminaria - poszerzające wiedzę ogólną,

- kursy, studia podyplomowe podnoszące poziom wykształcenia lub umożliwiające pozyskanie kwalifikacji,

- szkolenia stanowiskowe - ukierunkowane na rozwój specyficznych umiejętności wykorzystywanych w danej organizacji,

- instruktaż - realizowany przez przełożonego lub bardziej doświadczonych pracowników,

- coaching i mentoring - umożliwiający rozwój umiejętności, ale i kształtowanie postaw.

Podjęcie działań rozwojowych z wykorzystaniem każdej z tych metod może być zainicjowane przez indywidualną osobę lub też przez organizację zatrudniającą ją jako pracownika. W zrealizowanych badaniach przyjęto, że takie sytuacje mogą mieć również miejsce w odniesieniu do migrantów. W kraju goszczącym mogą oni samodzielnie podejmować decyzje o dokształcaniu, rozwoju lub mogą uczestniczyć w różnego rodzaju aktywnościach, na które kieruje ich pracodawca. Dodatkowo istotną formą wzbogacania kapitału ludzkiego jest samo wykonywanie obowiązków zawodowych, gdyż ze względu na potencjalne różnice występujące między przedsiębiorstwami i specyfiką rynku w kraju ojczystym i goszczącym nowe doświadczenia zawodowe mogą wpływać na pozyskanie wiedzy, rozwój umiejętności i kształtowanie postaw.

\subsection{Wpływ migracji na rozwój talentów}

Według danych GUS [2012], wzrost liczby osób wyjeżdżających do innych krajów europejskich w poszukiwaniu pracy po przystąpieniu Polski do UE (2004 do 2005) wynosił ponad 64\%. Pomimo że obecnie nie odnotowuje się już tak znaczącej dynamiki, wielu polskich obywateli wciąż podejmuje decyzję o podjęciu pracy za granicą, a migracja jest kluczowym czynnikiem determinującym zmiany na rynku pracy w Europie. Powody migracji są najczęściej analizowane z uwzględnieniem dwóch kategorii czynników: przyciągających i wypychających (pull-push factors) [King 2012]. Do czynników wypychających należą m.in.: brak zatrudnienia, brak perspektyw zawodowych czy zła sytuacja materialna. Do przyciągających zaliczyć można natomiast: lepsze perspektywy zawodowe, wyższe wynagrodzenie, lepszy standard życia [Zikic 2015]. 
W początkowych latach rozszerzenia UE kwestia migracji zarobkowej analizowana była głównie w kontekście „drenażu mózgów” (brain drain - utrata istotnych zasobów KL przez kraje, z których następowała migracja) oraz „pozyskiwania mózgów" (brain gain - wskazującego na korzyści uzyskiwane przez kraje przyjmujące) [Makulec 2013]. Ze względu na zmianę kierunków migracji, przenoszenie się migrantów między krajami, a przede wszystkim coraz częstsze powroty do krajów ojczystych zjawiska „drenażu i pozyskiwania mózgów” analizuje się obecnie w szerszym kontekście, definiując jako „cyrkulację/wymianę mózgów” (brain circulation/ exchange) [Zaiceva, Zimmermann 2012]. Zgodnie $\mathrm{z}$ tym podejściem migracja, a następnie powrót, przynosi trójstronne korzyści - dla kraju goszczącego, kraju pochodzenia oraz pracownika/migranta. Będąc za granicą migranci:

- wykorzystują w pracy zawodowej elementy KL nabyte w kraju ojczystym - co jest korzyścią dla kraju goszczącego,

- wzbogacają swoją wiedzę i umiejętności, wykonując nowe zadania; identyfikują swoje zdolności, predyspozycje dzięki pracy w odmiennym kulturowo środowisku oraz często wykonując pracę niezwiązaną z wyuczonym zawodem - co jest korzyścią dla migranta,

- wykorzystują pozyskane lub rozwinięte elementy KL w pracy zawodowej po powrocie - co jest korzyścią dla kraju ojczystego.

Zgodnie z nowym podejściem powrót do kraju pochodzenia jest naturalnym etapem, który następuje, gdy osoba wyjeżdżająca zrealizuje swoje cele. Cele te mogą dotyczyć m.in. pozyskania środków finansowych, rozwoju kompetencji czy zdobycia nowego doświadczenia [de Haas i in. 2015]. Korzyści w postaci wzbogacenia kapitału ludzkiego lub pozyskania kapitału finansowego są w dalszej kolejności przeznaczane na ustabilizowanie swojej sytuacji zawodowej w kraju pochodzenia.

Jedną z aktywności zawodowych, podejmowaną przez powracających migrantów, jest zakładanie własnej firmy. Na podstawie badań Naudé i in. [2015] wskazali, że powracający migranci, zakładający swoje firmy, odgrywają istotną rolę w rozwoju sektora MŚP oraz w tworzeniu miejsc pracy. Badania nad wyborami zawodowymi powracających migrantów potwierdzają, że korzyści i doświadczenia uzyskane za granicą pozytywnie wpływają na rozwój postaw przedsiębiorczych. Można zatem uznać, że migracja zarobkowa pozwala rozwijać kompetencje i aktywować/odkrywać zdolności wymagane do prowadzenia własnego biznesu.

\section{Cel i zakres badań}

Głównym celem przeprowadzonych badań była identyfikacja i analiza stopnia, w jakim wyjazd za granicę wspiera wzbogacanie kapitału ludzkiego wykorzystywanego w prowadzeniu własnej działalności gospodarczej. Założono, że w wyniku migracji następuje poszerzenie wiedzy, rozwój umiejętności, a także identyfikacja predyspozycji i zdolności, które pozytywnie wpływają na kształtowanie się postaw 
przedsiębiorczych. Dla przeprowadzonych badań sformułowano następujące pytania badawcze:

1. Czy wyjazd za granicę pozwolił na wzbogacenie kapitału ludzkiego w postaci pozyskania nowej wiedzy lub rozwoju umiejętności?

2. W jaki sposób nastąpiło wzbogacenie kapitału ludzkiego za granicą?

3. W jakim stopniu pozyskane komponenty kapitału ludzkiego były wykorzystane w zakładaniu własnej działalności gospodarczej?

Badania zostały przeprowadzone na grupie 54 polskich przedsiębiorców (zob. tab. 1), którzy przed założeniem firmy przebywali za granicą powyżej 12 miesięcy (założenie to wprowadzono, by wyeliminować krótkookresową/sezonową migrację zarobkową). W badaniach zastosowano dobór celowy respondentów, a kryteriami selekcji były: prowadzenie własnej działalności gospodarczej oraz okres przebywania na migracji (jak wspomniano wcześniej, minimum 12 miesięcy). Badania przeprowadzono z wykorzystaniem telefonicznego wywiadu kwestionariuszowego.

Tabela 1. Charakterystyka respondentów

\begin{tabular}{|c|c|c|}
\hline Kryterium & $N$ & $\%$ \\
\hline \multicolumn{3}{|c|}{ Płeć } \\
\hline Mężczyzna & 29 & 54 \\
\hline Kobieta & 25 & 46 \\
\hline \multicolumn{3}{|c|}{ Wiek } \\
\hline Poniżej 40 lat & 19 & 35 \\
\hline Między 40 a 45 lat & 19 & 35 \\
\hline 46 i więcej & 16 & 30 \\
\hline \multicolumn{3}{|c|}{ Poziom wykształcenia } \\
\hline Podstawowe & 1 & 2 \\
\hline Zawodowe & 12 & 22 \\
\hline Średnie & 30 & 56 \\
\hline Wyższe & 11 & 20 \\
\hline \multicolumn{3}{|c|}{ Sytuacja zawodowa przed wyjazdem } \\
\hline Bezrobotny/a & 11 & 20 \\
\hline Właśnie ukończyłem/am szkołę & 0 & 0 \\
\hline Prowadziłem/am własny biznes & 4 & 7 \\
\hline Studiowałem/am i pracowałem/am & 1 & 2 \\
\hline Pracowałem/am w mikrofirmie & 9 & 17 \\
\hline Pracowałem/am w małej firmie & 13 & 24 \\
\hline Pracowałem/am w średniej firmie & 2 & 4 \\
\hline Pracowałem/am w dużej firmie & 4 & 7 \\
\hline Zostałem zwolniony/a & 10 & 19 \\
\hline
\end{tabular}

Źródło: badania własne. 
Większość respondentów powróciła do Polski w ciągu ostatnich 5 lat (61\%) i w $70 \%$ przypadków są to osoby do 45 roku życia. Większość badanych przed wyjazdem miała wykształcenie średnie (56\%), a dodatkowe $22 \%$ wykształcenie zawodowe. W momencie wyjazdu $39 \%$ badanych nie posiadało pracy $-20 \%$ było bezrobotnych, a 19\% zostało zwolnionych.

Tabela 2. Charakterystyka przedsiębiorstw

\begin{tabular}{|c|c|c|}
\hline Kryterium & $N$ & $\%$ \\
\hline \multicolumn{3}{|l|}{ Okres funkcjonowania } \\
\hline Do 18 miesięcy & 15 & 28 \\
\hline 19-36 miesięcy & 13 & 24 \\
\hline 37-72 miesiące & 12 & 22 \\
\hline Pow. 72 miesięcy & 14 & 26 \\
\hline \multicolumn{3}{|c|}{ Profil działalności } \\
\hline Budownictwo, wykończenie wnętrz & 15 & 28 \\
\hline Handel detaliczny & 6 & 11 \\
\hline Usługi dla osób starszych & 5 & 9 \\
\hline Fryzjerstwo & 5 & 9 \\
\hline Usługi gastronomiczne, catering & 4 & 7 \\
\hline Usługi transportowe & 4 & 7 \\
\hline Architektura, projektowanie wnętrz & 3 & 6 \\
\hline Usługi porządkowe, sprzątanie & 3 & 6 \\
\hline Pozostałe & 2 & 17 \\
\hline \multicolumn{3}{|c|}{ Rynek działania } \\
\hline Lokalny & 28 & 52 \\
\hline Regionalny & 14 & 26 \\
\hline Krajowy & 8 & 15 \\
\hline Międzynarodowy & 4 & 7 \\
\hline
\end{tabular}

Źródło: badania własne.

Przedsiębiorstwa założone przez badanych migrantów działają głównie na rynku lokalnym (52\%) lub regionalnym (26\%). Wśród profilu działalności dominują usługi (zob. tab. 2). Ponad jedna czwarta badanych prowadzi firmę zajmującą się budownictwem lub wykończeniem wnętrz.

\section{Wyniki badań}

Większość respondentów (72\%) deklaruje, że pozyskała nową wiedzę, pracując za granicą (zob. tab. 3). Nowa wiedza powiązana była najczęściej z wyuczonym 
zawodem (39\%), jednak w 33\% przypadków umożliwiła podjęcie nowych zadań. W odniesieniu do umiejętności rozwój zadeklarowało 78\% badanych (zob. tab. 3 ). W ponad połowie przypadków rozwinięte umiejętności umożliwiły wykonywanie nowych i bardziej złożonych zadań, co wskazuje na istotną korzyść uzyskaną przez migrantów.

Tabela 3. Pozyskanie nowej wiedzy i rozwój umiejętności

\begin{tabular}{|l|c|c|}
\hline \multicolumn{1}{|c|}{ Czy będąc za granicą, pozyskał Pan/i nową wiedzę? } & $N$ & $\%$ \\
\hline Tak, tę powiązaną z wyuczonym zawodem & 21 & 39 \\
\hline Tak, pozwalającą na wykonywanie nowych, bardziej złożonych zadań & 18 & 33 \\
\hline Tak, tę niepowiązaną z moim zawodem, umożliwiającą znalezienie pracy & 5 & 9 \\
\hline Nie, nie pozyskałem/am nowej wiedzy & 15 & 28 \\
\hline Czy będąc za granicą, rozwinął Pan/i swoje umiejętności? & $N$ & $\%$ \\
\hline Tak, te bezpośrednio powiązane z moim zawodem & 8 & 15 \\
\hline Tak, pozwalające na wykonywanie nowych bardziej złożonych zadań & 29 & 54 \\
\hline Tak, te niepowiązane z moim zawodem, umożliwiające znalezienie pracy & 5 & 9 \\
\hline Nie, nie rozwinąłem/am umiejętności & 12 & 22 \\
\hline
\end{tabular}

Źródło: badania własne.

Pozyskanie nowej wiedzy i rozwój umiejętności nastąpił głównie przez realizację bardziej złożonych i zróżnicowanych zadań - taką odpowiedź wskazał co trzeci badany (zob. tab. 4). Nowa wiedza w $33 \%$ przypadków została pozyskana dzięki instrukcjom przekazywanym przez bardziej doświadczonych pracowników. Taką formę rozwoju umiejętności wskazał również niemal co piąty badany. Relatywnie niski jest udział bardziej ustrukturyzowanych, sformalizowanych form rozwoju kompetencji. W przypadku wiedzy $24 \%$ respondentów deklaruje, że pozyskało ją dzięki uczestnictwu w szkoleniach i kursach (organizowanych przez pracodawców lub wynikających z własnej inicjatywy), w przypadku umiejętności udział ten był niższy i wynosił $13 \%$. Ponad jedna czwarta respondentów pozyskała nową wiedzę poprzez samokształcenie.

Wyniki przeprowadzonych badań wskazują, że pozyskana wiedza i rozwinięte umiejętności są wykorzystywane obecnie przy prowadzeniu własnej firmy, przy czym wiedza ma większe znaczenie niż umiejętności. Ponad połowa badanych (52\%) wskazuje, że pozyskana wiedza jest obecnie kluczowa lub wykorzystywana $w$ dużm stopniu. W przypadku umiejętności udział tych odpowiedzi wynosi $48 \%$.

Istotnym elementem badań było również pozyskanie informacji o tym, w którym momencie migranci podjęli decyzję o założeniu własnej firmy - czy pomysł pojawił się przed wyjazdem, w jego trakcie czy po powrocie do kraju. Większość respondentów postanowiła założyć własny biznes w trakcie pobytu za granicą (46\%) (zob. tab. 6), jednak ponad jedna trzecia z nich musiała go zmodyfikować po powro- 
Tabela 4. Sposoby pozyskiwania nowej wiedzy i rozwoju umiejętności

\begin{tabular}{|l|c|c|}
\hline \multicolumn{1}{|c|}{ W jaki sposób pozyskał/a Pan/i nową wiedzę } & $N$ & $\%$ \\
\hline Poprzez realizację bardziej złożonych i zróżnicowanych zadań & 18 & 33 \\
\hline $\begin{array}{l}\text { Dzięki instrukcjom przekazywanym przez bardziej doświadczonych } \\
\text { współpracowników }\end{array}$ & 18 & 33 \\
\hline Poprzez udział w szkoleniach, kursach organizowanych przez pracodawcę & 6 & 11 \\
\hline Poprzez udział w szkoleniach, kursach, na które sam/a się zapisałem/am & 7 & 13 \\
\hline Poprzez samokształcenie & 14 & 26 \\
\hline & $N$ & $\%$ \\
\hline Poprzez realizację bardziej złożonych i zróżnicowanych zadań & 18 & 33 \\
\hline $\begin{array}{l}\text { Dzięki instrukcjom przekazywanym przez bardziej doświadczonych } \\
\text { współpracowników }\end{array}$ & 12 & 22 \\
\hline Poprzez udział w szkoleniach, kursach organizowanych przez pracodawcę & 6 & 11 \\
\hline Poprzez udział w szkoleniach, kursach, na które sam/a się zapisałem/am & 1 & 2 \\
\hline Poprzez obserwację bardziej doświadczonych współpracowników & 5 & 9 \\
\hline
\end{tabular}

Źródło: badania własne.

Tabela 5. Stopień wykorzystania wiedzy i umiejętności pozyskanych za granicą

\begin{tabular}{|c|c|c|}
\hline $\begin{array}{l}\text { W jakim stopniu pozyskana wiedza jest wykorzystywana obecnie } \\
\text { przy prowadzeniu własnej działalności? }\end{array}$ & $N$ & $\%$ \\
\hline Jest kluczowa, dzięki niej prowadzę obecny biznes & 7 & 13 \\
\hline Jest wykorzystywana w dużym stopniu & 21 & 39 \\
\hline Jest wykorzystywana częściowo & 10 & 19 \\
\hline Raczej nie jest wykorzystywana & 0 & 0 \\
\hline Zupełnie nie jest wykorzystywana & 1 & 2 \\
\hline $\begin{array}{l}\text { W jakim stopniu umiejętności te są wykorzystywane obecnie } \\
\text { przy prowadzeniu własnej działalności? }\end{array}$ & $N$ & $\%$ \\
\hline Są kluczowe, dzięki nim prowadzę swój obecny biznes & 5 & 9 \\
\hline Są wykorzystywane w dużym stopniu & 21 & 39 \\
\hline Są wykorzystywane częściowo & 13 & 24 \\
\hline Raczej nie są wykorzystywane & 1 & 2 \\
\hline Zupełnie nie są wykorzystywane & 2 & 4 \\
\hline
\end{tabular}

Źródło: badania własne.

cie. Blisko co czwarty badany (26\%) zadeklarował, że pomysł pojawił się dopiero po powrocie, a 28\% miało już koncepcję własnej firmy przed wyjazdem.

Respondenci zostali również zapytani, czy przy zakładaniu firmy potrzebne były szczególne uzdolnienia i umiejętności i czy nabyli je w trakcie migracji. Według 39\% badanych rozpoczęcie własnej działalności wymagało szczególnych kompe- 
Tabela 6. Moment, w którym pojawił się pomysł na własny biznes

\begin{tabular}{|l|c|c|}
\hline $\begin{array}{l}\text { Które z poniższych określeń najlepiej opisuje proces tworzenia koncepcji firmy, } \\
\text { tego, jakie produkty i usługi będzie ona świadczyła? }\end{array}$ & $N$ & $\%$ \\
\hline Pomysł powstał jeszcze przed wyjazdem za granicę & 15 & 27,5 \\
\hline Pomysł powstał, gdy byłem/-am za granicą & 15 & 27,5 \\
\hline $\begin{array}{l}\text { Pomysł powstał, kiedy byłem/-am za granicą, jednak po powrocie do kraju wy- } \\
\text { magał modyfikacji }\end{array}$ & 10 & 19 \\
\hline Pomysł powstał dopiero po powrocie do kraju & 14 & 26 \\
\hline
\end{tabular}

Źródło: badania własne.

tencji, a dwie trzecie z nich rozwinęło je za granicą. Uczestnicy badania wskazali również dodatkowe, związane z migracją, korzyści w zakresie rozwoju KL. Co czwarty badany uznał, że wyjazd był ciekawym doświadczeniem życiowym, które umożliwiło rozwój osobisty (poprzez: nabycie pewności siebie, większa samoświadomość, zwiększenie odporności na stres, wzrost samooceny). Dodatkowo $26 \%$ badanych stwierdziło, że nabyli cenne doświadczenie zawodowe, $17 \%$ wskazało na poszerzenie swojej wiedzy, $11 \%$ na rozwój umiejętności, a 15\% na poprawę znajomości języka obcego.

\section{Podsumowanie i wnioski}

Uzyskane wyniki wskazują, że migracja wzbogaciła kapitał ludzki badanych osób. Nawiązując do przedstawionych w pierwszej części artykułu rozważań, należy wskazać, że wyjazd za granicę w istotny sposób przyczynił się do nabycia lub rozwoju poszczególnych jego komponentów, które wykorzystywane są w prowadzeniu własnej działalności gospodarczej. Potwierdza to fakt, że jedynie $7 \%$ badanych prowadziło przed wyjazdem własny biznes i tylko $28 \%$ miało pomysł na firmę przed wyjazdem. W pozostałych przypadkach praca za granicą pozwoliła na pozyskanie nowej wiedzy (w 33,3\% umożliwiającej realizowanie nowych zadań, w 9,3\% niezwiązanej z zawodem), rozwój umiejętności (w 53,7\% umożliwiających realizowanie nowych zadań, w 9,3\% niezwiązanych z zawodem), a także rozwój osobisty (większa samoświadomość, wyższa samoocena, odporność na stres). Pozyskana wiedza i umiejętności są w wielu przypadkach kluczowe lub wykorzystywane w dużym stopniu przy prowadzeniu firmy. W odniesieniu do badanych przedsiębiorców miarą tej efektywności może być rozwój i sukces własnego biznesu. W 72\% firmy te działają na rynku ponad 18 miesięcy, co wskazuje na przetrwanie najtrudniejszego okresu funkcjonowania - według danych PARP [2017] przeżywalność firm z sektora MŚP w pierwszym roku wynosi $68,9 \%$.

Wyniki przeprowadzonych badań potwierdzają również, że w badanej grupie przedsiębiorców w większym stopniu występuje zjawisko ,,cyrkulacji/wymiany mózgów” niż „drenażu”. Osoby te podczas pobytu za granicą wykorzystywały wiedzę 
i umiejętności nabyte w Polsce, jednak zgodnie z udzielonymi odpowiedziami w trakcie migracji wzbogaciły posiadane kompetencje. Powrót do kraju oraz stopień wykorzystania nowej wiedzy i umiejętności w prowadzeniu biznesu wskazuje, że osoby te czerpią korzyści z rozwoju, jaki miał miejsce w kraju goszczącym. Fakt, że większość z tych osób (93\%) nie prowadziła własnej działalności przed wyjazdem, pozwala stwierdzić, że w trakcie pobytu za granicą osoby te zidentyfikowały u siebie predyspozycje lub zdolności do podejmowania działań przedsiębiorczych.

\section{Literatura}

Becker G.S., 1962, Investment in human capital: A theoretical analysis, The Journal of Political Economy, volume 70, Issue 5, part 2.

De Haas H., Fokkema T., Fihri M.F., 2015, Return migration as failure or success? Journal of International Migration and Integration, 16(2), s. 415-429.

GUS, 2012, Informacja o rozmiarach i kierunkach emigracji z Polski $w$ latach 2004-2011, Materiały na konferencję prasową w dniu 25.09.2012, Źródło https://stat.gov.pl/cps/rde/xbcr/gus/LU_infor_o_rozm_i_kierunk_emigra_z_polski_w_latach_2004_2011.pdf.

King R., 2012, Theories and typologies of migration: An overview and primer, Willy Brandt Series of Working Papers in International Migration and Ethnic Relations, http://www.mah.se/upload/ Forskningscentrum/MIM/WB/WB\%203.12.pdf.

Lipka A., 2010, Inwestycje w kapitał ludzki organizacji w okresie koniunktury i dekoniunktury, Oficyna a Wolters Kluwer Business, Warszawa.

Makulec A., 2013, Konsekwencje migracji wysoko wykwalifikowanego kapitału ludzkiego dla krajów wysyłających i migrantów na przykładzie personelu medycznego, CMR Working Papers 61/119, Centrum badań nad migracjami Uniwersytetu Warszawskiego, http://www.migracje.uw.edu.pl/ wp-content/uploads/2016/10/Makulec_CMR_WORKING_PAPER_FIN_1.pdf.

Naudé W., Siegel M., Marchand K., 2015, Migration, entrepreneurship and development: A critical review, UNU-MERIT Working Papers.

Pocztowski A., 2007, Zarządzanie Zasobami Ludzkimi, PWE, Warszawa.

Raport o stanie sektora małych i średnich przedsiębiorstw w Polsce 2017, Polska Agencja Rozwoju Przedsiębiorczości, Warszawa, https:/www.parp.gov.pl/images/PARP_publications/pdf/raport $\% 200 \% 20$ stanie $\% 20$ sektora $\% 20 \mathrm{msp} \% 20 \mathrm{w} \% 20$ polsce_2017.pdf.

Sandberg J., Pinnington A. H., 2009, Professional competence as ways of being: an existential ontological perspective, Journal of Management Studies, vol. 7, no. 46, s. 1138-1170.

Zaiceva A., Zimmermann K.F., 2012, Returning Home at Times of Trouble? Return Migration of EU Enlargement Migrants during the Crisis, no. 7111, Institute for the Study of Labor (IZA).

Zikic J., 2015, Skilled migrants' career capital as a source of competitive advantage: implications for strategic HRM, The International Journal of Human Resource Management, vol. 26, no. 10, s. $1360-1381$. 